\title{
Pressure grows for inquiry into welfare of transgenic animals
}

[LONDON] Public concern in Britain over the increasing use of animals in genetics research is fuelling calls for a commission of inquiry to investigate the welfare of transgenic animals. The calls come in the wake of the UK government's decision last month to shelve an earlier promise to set up a broadranging royal commission on the use of animals in medical research.

Organizations on both sides of the animal experiments debate say they are relieved that plans for a wide-ranging royal commission have been abandoned. But many now want the government to focus on transgenic animals, an issue they believe is of more immediate public concern.

A recent survey supported by the European Commission into public attitudes to biotechnology showed that most respondents in European Union countries consider the creation of transgenic animals, for research and for xenotransplants, to be morally unacceptable (see Nature 387, 845-847; 1997).

The issue was highlighted in last week's debate in the European Parliament on biotechnology patent legislation, and has also become central to a national referendum on the applications of genetic engineering to be held in Switzerland next year (see pages 314 and 315). Abby Munson, a spokeswoman for the Genetics Forum, says governments can no longer ignore such concerns. "The science is progressing at such a speed that the public feels left behind."
Significantly, in the United Kingdom at least, while the numbers of animals involved in research has been dropping, the numbers of transgenic animals bred increased fourfold between 1990 and 1995, when 215,000 animals were produced. This figure is expected to increase further when statistics for 1996 are released by the government today (24 July).

The proposal for a commission on transgenic animals has come from Maggy Jennings, head of the 'animals in research' division of the Royal Society for the Prevention of Cruelty to Animals. The idea has many supporters, including the Fund for the Replacement of Animals in Medical Experiments (FRAME), the pressure groups, Genetics Forum and Advocates for Animals.

The idea of studying the implications of the increasing use of transgenic animals also has support from a number of scientists, including Colin Blakemore, professor of physiology at the University of Oxford.

Under the 1986 Animals (Scientific Procedures) Act — widely considered to be among the toughest pieces of legislation in the world, and which is currently being reviewed - all animals used in research need to be licensed by the Home Office's Animal Procedures Committee. The legislation is framed according to a cost-benefit approach - a procedure will be licensed if the benefits to humans, or other animal species, outweigh the costs, in terms of suffering, to the animal used in the research.

\section{CNRS gets first woman director general}

[PARIS] Catherine Bréchignac, a physicist, last week became the first woman director general of the French Centre National de la Recherche Scientifique (CNRS), succeeding Guy Aubert, whose three-year term had expired.

The new Socialist government also appointed Gérard Brachet as director general of the French space agency, CNES, a post that had been abolished in January last year (see Nature 379, 476; 1996).

Bréchignac, who is $\mathbf{5 1}$ years old, is wellrespected as a scientist - she has worked on atomic clusters - and as a manager. Since November 1995 she has headed CNRS's Department of Physical Sciences and Mathematics.

Her task as director general is likely to be substantial, given that Claude Allègre, the dynamic minister for education, research and technology, is keen to see a broad reform of research strategy within CNRS, as well as in universities and other public research organizations (see Nature 388,$7 ; 1997$ ).

Allègre has complained that CNRS has become "an immense bureaucracy", and he intends to reduce the organization's central management and to transfer staff to reinforce the university system.

Allègre's unhappiness with France's space policy suggests that Brachet's job will be no less difficult. One task is expected to be to reorientate the space agency's activities so that they are driven less by politics and more by "technical and scientific aspects".

In a recent interview with the newspaper Le Monde, Allègre described the agency's policies as "stupefying", criticizing the excessive weight of its contribution to the European Space Agency and complaining that CNES's own objectives were far from clear.

Declan Butler

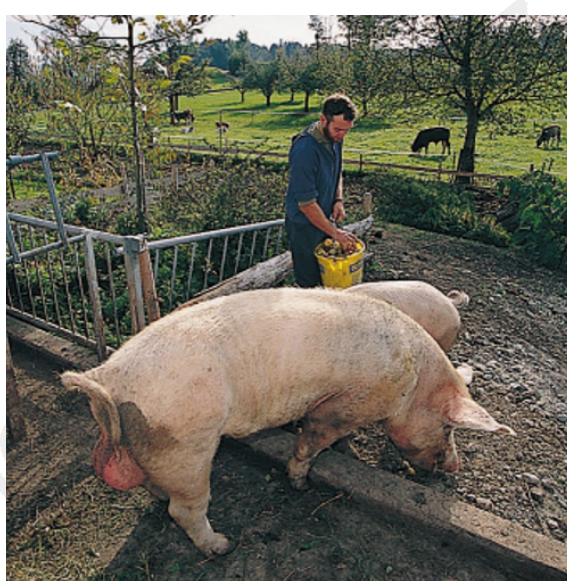

Pigs in the middle: Switzerland will vote next year on banning transgenic experiments (see page 315 ).

But Blakemore acknowledges that since the act was passed, in some instances the costs to the animals used have been increasing along with the "enormous" benefits to humans. "In some cases, the potential suffering may have increased to the point where it may be unacceptable. It is almost like saying 'would it ever be justifiable to kill people if the benefit was a guaranteed cure for cancer?'. The answer is, of course, 'no', but that is the direction we're heading in."

Blakemore says he would welcome an inquiry into transgenic animals, rather than a broad-ranging royal commission on animal testing, as the latter would reopen issues that have already been settled. But he adds that inquiries need to have a bottom line namely that the use of animals in research should not be banned, as ultimately there will always be benefits to humans.

Some in the animal rights movement would still prefer a broad royal commission on animals in research. The British Union for the Abolition of Vivisection believes that neither an inquiry into transgenic animals nor a review of the animals procedures act is a proper substitute for a broad and objective inquiry into the whole question.

Mike Baker, the union's director, does not believe that the current review of the act will be sufficiently objective, as he says the government's Animal Procedures Committee which is carrying out the review - is dominated by individuals with a research background, or at least an interest in research.

Although not opposed to an inquiry into transgenic animals, he argues that the issue was adequately dealt with by two reports on xenotransplants published earlier this year. One was commissioned by the Department of Health under the previous Conservative government, the other was 
from the Nuffield Council on Bioethics.

Ian Kennedy, professor of law and medical ethics at King's College, London, who chaired the xenotransplants panel commissioned by the previous government, says the question of the ethics of transgenic animals was looked at in detail. But David Shapiro, executive secretary of the Nuffield Council on Bioethics, says that the issue of transgenic animals was only "touched on" in the council's report, and is oriented towards their use as a source of xenografts.

Baker argues that the topic of transgenic animals will resurface in a review of biotechnology and the patenting of animals which was also promised in the Labour party's preelection policy document, New Labour, New Life for Animals. Indeed, some are pressing Britain's science minister, John Battle, to raise this issue when the European patent directive is discussed by the Council of Ministers.

But Baker's could be a minority voice. Les Ward, director of Advocates for Animals, says his experience of royal commissions is that "they tend to be talking-shops with little impact. Governments sometimes use them to deflect public opinion."

Some organizations say they were never enthusiastic about the proposal, but kept quiet about their reservations in an attempt not to embarrass Elliot Morley, the former Labour spokesman on animal welfare, whose idea it was. Morley is now a junior minister responsible for 'fish and countryside' in the Ministry of Agriculture, but is no longer responsible for animal welfare.

But the decision not to proceed with the royal commission remains controversial because it was understood to have been a preelection promise. Some Labour members of parliament — including Anne Campbell, recently appointed as a parliamentary private secretary to Battle - appear to have been taken by surprise by the government's decision not to proceed.

Others are concerned that the decision could be interpreted as an indication that the new government makes promises in haste, and then fails to keep them. Lynne Jones (Labour, Birmingham Selly Oak) says she was "somewhat taken aback" by the decision, having thought that a commission was official Labour party policy.

Indeed, three weeks before the 1 Maygeneral election, Morley confirmed that Labour had promised a royal commission to look at the whole issue of animal experimentation.

Government sources now argue that the royal commission was never a firm manifesto promise, but was rather a promise made in New Labour, New Life for Animals to "support" a royal commission.

Civil servants are understood to have been concerned that taking on a royal commission would have created additional stress in what is already an ambitious legislative timetable.

EhsanMasood

\section{NSF urged to increase plant genome sequencing effort}

[WASHINGTON] A \$40 million-a-year initiative at the US National Science Foundation to sequence a plant genome has been proposed by a key Senate committee, and could be under way by the end of this year.

The initiative is being vigorously promoted by Senator Christopher Bond (Republican, Missouri) at the prompting of US corn-growers, who are excited about the potential of genetically engineered crops to increase yields.

Scientists are convinced that the proposed initiative would support first-rate science and speed up the sequencing of the genome of corn and other crops. But some are also concerned that the proposal is so large that every other area of university science at the NSF would lose out to pay for it.

Last week, Bond earmarked \$40 million for a plant genome initiative in the budget bill prepared by the appropriations subcommittee of the Senate Veterans Affairs, Housing and Urban Development and independent agencies (VA-HUD), which he chairs.

Bond claims that the project is "key to keeping America number one in agriculture in the next century". It is said to be his top personal priority in the entire $\$ 40$-billion VA-HUD bill.

Agricultural interests, encouraged by the generally positive response to last summer's introduction of genetically engineered cotton crops (see Nature 387, 221; 1997), and aware of Japan's recent pledge to sequence the rice genome, are pushing for a coordinated effort corresponding to the Human Genome Project in the biomedical field.

The main concern of scientists is that Bond's initiative would consume half the extra money his committee wants to make available to the NSF next year, leaving other fields of science with an increase less than the rate of inflation, and dashing hopes that the science agency would have more money for general university research this year.

Together with the energy and agriculture departments, the NSF is engaged in a \$6-million-a-year project to sequence the genome of Arabidopsis, a mustard plant selected for early study because of its relatively small genome. Last year, this project was incorporated into a global effort.

Neal Lane, director of the NSF, pointed out last week that the agency already spends about $\$ 20$ million on plant genome research in total. But a member of Bond's staff says that the $\$ 40$ million is expected to pay for new work on top of the existing activity.

Officials from the NSF, the White House and both houses of Congress are expected to hold negotiations between now and Septem-

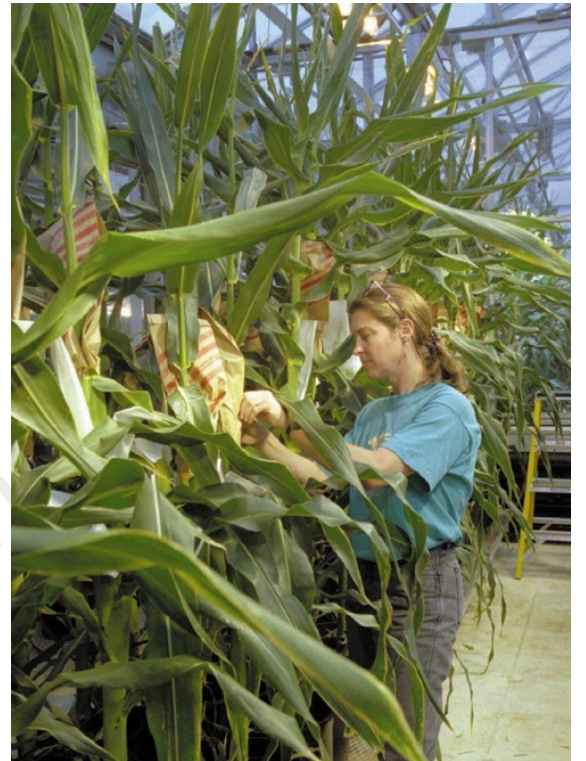

Genetic futures: companies like DeKalb Genetics Corp (above) may gain from sequencing project.

ber, when the budget is finalized, on the final shape of the initiative. "We all agree that this is something we should be doing," Bond's aide says. "It is not something we're going to fight about."

In April, Bond's subcommittee asked the White House to create an interagency working group on plant genomes. In a preliminary report last month, the group rejected an immediate project to sequence the corn genome on cost and benefit grounds. But it did endorse the principle of a plant genome initiative, to be led, it suggested, by the US Department of Agriculture, to lay the groundwork for future sequencing efforts.

Corn has a genome six times the size of that of of rice and 17 times the size of that of Arabidopsis. The wheat genome is much larger still: six times larger than the corn genome. The working party said that the Arabidopsis work would help development of the powerful computer tools that would be needed to handle the larger genomes of the crop plants.

The NSF has traditionally fought off attempts by the Congress to tell it what research to do. But in this case, concern about the agency's independence may be alleviated by a widespread perception that plant genome research has been unfairly neglected in comparison to human genome research, which now has an institute of its own at the National Institutes of Health with an annual budget of almost $\$ 200$ million.

"We've been trying to make the argument that plant biotechnology is important for 20 years," says Mary Clutter, associate director of life sciences at the NSF.
ColinMacilwain 